\title{
PARTISIPASI MASYARAKAT DESA MALASARI DALAM PENGEMBANGAN EKOWISATA TAMAN NASIONAL GUNUNG HALIMUN SALAK (TNGHS)
}

\author{
Rezka Fedrina \\ NIDN 0008027613 \\ Email: rezka-fedrina@unj.ac.id \\ Fakultas Ilmu Sosial, Universitas Negeri Jakarta
}

\begin{abstract}
Malasari village is a village located in the Halimun Salak Mountain National Park. During this time the community utilizing national park area for the sake of the livelihood of particularly with regard to forest products. Later in its development with the potential of nature, the tour be an alternative solution for the people of the village of Malasari. The purpose of this research is to know the form of participation by the village of Malasari in the development of Ecotourism Halimun. This research used the qualitative approach with descriptive analytical method. The collection of data using interviews and observations in the field. The data collected was then analysed qualitatively the results showed that the participation of the community of the village of Malasari was formed in 4 stages, namely the participation in decision-making, implementation and utilization as well as evaluation. Based on the results of such research, then there is need for more research on how the level of community participation and efforts for its increase in the ideal pattern of development of ecotourism Village Malasari
\end{abstract}

Keywords: Ecotourism, Participation, National Park

\section{PENDAHULUAN}

Ekowisata merupakan suatu bentuk aktivitas wisata yang berkelanjutan dan bertanggung jawab terhadap area alami dengan tujuan konservasi lingkungan serta melestarikan kehidupan dan menyejahterakan masyarakat sekitar (The Ecotourism Societ (TIES),2015). Ekowisata menekankan pentingnya konservasi lingkungan serta kesejahteraan masyarakat penyelenggara ekowisata. Ekowisata merupakan aktivitas yang ramah lingkungan dan sanggup mendukung konservasi keanekaragaman hayati. Ekowisata merupakan sebuah bentuk pariwisata yang menekankan partisipasi masyarakat dalam pengembangannya (Baksh, dkk., 2012)

Desa Malasari merupakan salah satu di antara desa yang terletak dalam kawasan Taman Nasional Gunung Halimun Salak (TNGHS) dan pada beberapa kampung dari wilayah Desa Malasari terletak dalam wilayah pengelolaan TNGHS. Desa Malasari sebagai desa yang berada di wilayah TNGHS merupakan desa yang secara langsung merasakan dampak dari kegiatan ekowisata di TNGHS. Aktivitas wisatawan yang ingin berkunjung untuk

menikmati keindahan alam telah menjadi aktivitas ekonomi sampingan yang kemudian dimanfaatkan oleh masyarakat.

Kegiatan ekowisata pada prinsipnya haruslah menekankan kepada adanya partisipasi dari masyarakatnya, kepemilikan maupun peluang usaha khususnya bagi masyarakat (Eko Budi Santoso,2017: 6). Adapun masyarakat Desa Malasari saat ini telah berpartisipasi dalam aktivitas ekowisata di TNGHS, dimana hal ini tidak terlepas dari berbagai faktor yang mempengaruhinya. Berbagai bentuk partisipasi masyarakat Desa Malasari dalam pengembangan ekowisata di TNGHS mampu memberikan berbagai manfaat baik itu secara sosial, ekonomi dan budaya mampu memberikan berbagai manfaat terhadap masyarakat Desa Malasari yang memiliki potensi untuk dikembangkan menjadi destinasi wisata unggulan di Kabupaten Bogor. Adapun karakteristik umum dari ekowisata adalah melibatkan apresiasi bukan hanya kepada alam tetapi juga terhadap budaya-budaya pribumi; 
berisikan pendidikan dan interpretasi sebagai bagian dari tawaran kepada wisatawan, umumnya, tetapi tidak secara eksklusif, diorganisasikan bagi kelompokkelompok kecil oleh pemilik usaha lokal yang berspesialisasi, meminimalisir dampak-dampak negatif pada alam maupun lingkungan sosial-budaya, mendukung perlindungan area-area alami melalui keuntungan ekonomi yang diperoleh bagi pengelola-pengelola area-area alami, menyediakan pendapatan dan pekerjaan alternatif bagi komunitas-komunitas lokal dan meningkatkan kesadaran masyarakat lokal maupun wisatawan yang berkunjung mengenai kesadaran akan pentingnya konservasi.

( UNEP\&WWF,2001)

Berdasarkan latar belakang masalah diatas maka rumusan masalah pada penelitian ini adalah bagaimana partisipasi masyarakat Desa Malasari dalam pengembangan ekowisata Taman Nasional Gunung Halimun Salak.

\section{LITERATUR REVIEW}

Pendekatan ekowisata yang berbasiskan kepada partisipasi masyarakat adalah sebuah cara pandang mengenai pentingnya partisipasi masyarakat dalam pengembangan ekowisata serta prinsip pengutamaan masyarakat sebagai pihak yang mengambil keputusan, melaksanakan, memafaatkan dan mengevaluasi aktivitas ekowisata tersebut. Hal ini sesuai dengan Undang-Undang Republik Indonesia No 10 Tahun 2009 mengenai kepariwisataan dimana implikasi dari pembangunan kepariwisataan di Indonesia harus berdasarkan prinsip kepariwisataan yang melindungi dan mengkonservasi lingkungan serta memperhatikan keberlanjutannya yang meliputi lingkungan alam, sosial, ekonomi dan budaya masyarakat.

Terdapat berbagai pengertian mengenai partisipasi. Para ahli biasanya cenderung mendefinisikan arti kata tertentu dalam hal ini adalah kata "partisipasi" sesuai dengan minat pengetahuan yang menjadi fokus keahliannya mereka. Partisipasi berasal dari kata bahasa Inggris "participation" yang berarti pengambilan bagian, pengikutsertaan (Echols dan Shadily, 2012). Kamus besar bahasa Indonesia menyebutkan bahwa partisipasi artinya perihal turut berperan serta dalam suatu kegiatan. Partisipasi masyarakat yang ditelaah adalah berkenaan dengan keterlibatan mental dan emosional, inisiatif serta tanggung jawab masyarakat dalam perencanaan, pelaksanaan, dan pemantau-an dalam pengembangan ekowisata (Annisa,2017). Persepsi masyarakat yang dikaji berkenaan dengan partisipasi terbatas pada pengertian, interpretasi dan tanggapan masyarakat terhadap kegiatan ekowisata. Selanjutnya, sikap yang dikaji sehubungan dengan partisipasi terbatas pada sikap masyarakat terhadap program kebersihan, keindahan, kenyamanan, dan keramahtamahan (Sri Hayati,2010:12-27).

Terdapat berbagai tahapan partisipasi masyarakat dalam proses pembangunan. Partisipasi masyarakat adalah keterlibatan masyarakat sesuai dengan hak dan kewajibannya sebagai subyek dan obyek pembangunan. Partisipasi masyarakat dibedakan ke dalam empat tahap (Siti .I,2011:61) yaitu:

1. Pertama, partisipasi dalam pengambilan keputusan. Partisipasi ini bersifat sangat penting karena pengambilan keputusan merupakan suatu proses pemilihan alternatif berdasarkan pertimbangan yang menyeluruh dan bersama. Dibutuhkan kesepakatan dan suara mufakat karena bagaimanpun juga kegiatan terselenggara demi kepentingan bersama. Wujud partisipasi masyarakat dalam pengambilan keputusan ini bermacammacam, seperti kehadiran rapat, diskusi, sumbangan pikiran, tanggapan atau penolakan terhadap program yang ditawarkan .

2. Kedua, partisipasi dalam pelaksanaan. Partisipasi dalam pelaksanaan. Ini adalah jenis partisipasi yang menjadi salah satu unsur dalam penentu keberhasilan program itu sendiri. Ruang lingkup partisipasi dalam pelaksanaan meliputi 
menggerakkan sumber daya dan dana, kegiatan administratif dan koordinasi serta penjabaran program. Sifat gotong royong serta kesadaran dari setiap masyarakat dalam pelaksanaan pembangunan desa sanggat dibutuhkan. Karena tanpa adanya bantuan gotong royong dari masyarakat desa, pelaksanaan pembangunan yang baik ialah pembangunan yang tumbuh dari kesadaran dan kepedulian yang dilaksanakan oleh masyarakat dengan sifat sukarela atau dengan sepenuh hati yang nantinya akan merasakan dampak positif dari setiap hasil pelaksanaan kegiatan pembangunan desa sendiri. Halhal yang mempengaruhi partisipasi masyarakat dalam perencanaan pembangunan desa adalah rsa kurang kepedulian dari masyarakat yang lebih mementingkan kepentingan atau kesibukan masing-masing. Padahal kepedulian dari masyarakat yang

3. nantinya akan memberikan perkembangan atau pertumbuhan bagi pembangunan desa yang ada.

4. Ketiga, partisipasi dalam pengambilan manfaat yaitu partisipasi yang terkait dengan kualitas dan kuantitas dari hasil pelaksanaan program yang dicapai. Partisipasi dalam bentuk menggunakan, menjaga, merawat dan memelihara setiap hasil pembangunan desa, karena masyarakat merupakan objek yang terlibat langsung dalam penggunaan dan pemeliharaan hasil pembangunan. Tetapi dalam pengambilan pemanfaatan, perawatan dan pemeliharaan hasil pembangunan kesadaran dan kepedulian masyarakat masih kurang yang terkandang membuat setiap pembangunan desa yang sudah dibangun mengalami kerusakan. Padahal menjaga, merawat dan memlihara setiap hasil pembangunan desa itu adalah merupakan bagian atau tugas dari masyarakat yang menggunakannya.

5. Keempat, partisipasi dalam evaluasi. Partisipasi ini bertujuan untuk mengetahui bagaimana pelaksanaan program berjalan, apakah sudah sesuai dengan tujuan yang ingin dicapai atau. ini lebih kepada penilaian dalam mengawasi dan mengontrol setiap perencanaan pembangunan yang akan berjalan. Tujuan dari evaluasi ini juga dapat dijadikan pembelajaran dan bahan pertimbangan dalam melakukan pelaksanaan kegiatan pembangunan desa kedepan. Untuk melakukan evaluasi hasil perencanaan pembangunan tersebut biasanya pemerintah melakukan rapat atau pertemuan dengan melibatkan masyarakat yang membahas dan membicarakan hasilhasil dari rencana pembangunan desa yang akan direncanakan. Pada proses evaluasi selain membicarakan hasil-hasil dari rencana pembangunan yang akan dilaksanakan, masyarakat juga sering melakukan penilaian berupa menyampaikan kritikan dan saran mengenai rencana pembangunan desa yang akan dilaksanakan kepada pemerintah, karena saat dalam proses perencanaan pembangunan desa pemerintah kurang memberikan perhatian kepada masyarakat. Selain kritikan, masyarakat juga menyampaikan saran kepada pemerintah agar proses rencana pembangunan desa kedepan boleh berjalan lebih baik

Ada tiga alasan utama mengapa partisipasi masyarakat mempunyai sifat sangat penting. Pertama, partisipasi masyarakat merupakan suatu alat guna memperoleh informasi mengenai kondisi, kebutuhan dan sikap masyarakat setempat, yang tanpa kehadirannya program pembangunan serta proyek-proyek akan gagal. Kedua, masyarakat akan lebih mempercayai proyek atau program pembangunan jika merasa dilibatkan dalam proses persiapandan perencanaannya, karena mereka akan lebih mengetahui seluk beluk proyektersebut dan akan mempunyai rasa memiliki terhadap proyek tersebut. Ketiga,timbul anggapan bahwa merupakan suatu hak demokrasi bila masyarakat dilibatkan dalam pembangunan masyarakat mereka sendiri. Dapat dirasakan bahwa 
merekapun mempunyai hak untuk turut memberikan saran dalam menentukan jenis pembangunan yang akan dilaksanakan. (Prastiwi M, 2010: 4).

\section{METODE PENELITIAN}

Pendekatan penelitian yang digunakan dalam penelitian ini adalah pendekatan penelitian kualitatif dengan mendeskripsikan berbagai fenomena yang terangkum dalam rumusan permasalahan penelitian ini. Data dalam penelitian ini diperoleh dengan metode observasi, wawancara, dan studi dokumen. Data yang diperoleh dianalisa dengan teknik analisis deskriptif kualitatif. Selanjutnya, hasil analisis data disajikan secara secara formal, yaitu dalam bentuk bagan, grafik, dokumen, gambar, dan sebagainya, dan secara informal yaitu dalam bentuk narasi.

\section{HASIL PENELITIAN}

Desa Malasari dengan luas wilayah 8.262,22 Ha, memiliki jumlah penduduk 8.417 dari 2314 kepala keluarga, 4 (Empat) kepala dusun yang terbagi 12 RT dan 49 RW yang mayoritas sebagai para petani

Tabel 1. Data Demografi Desa Malasari

\begin{tabular}{|c|c|c|c|c|c|}
\hline \multirow{2}{*}{ No } & \multirow{2}{*}{$\begin{array}{c}\text { KE.IOMPOK } \\
\text { UMUR }\end{array}$} & \multicolumn{2}{|c|}{ JUMLAH JIWA } & \multirow{2}{*}{ IUMLAII } & \multirow{2}{*}{ KLILLKANGAN } \\
\hline & & LAKI LAKI & PEREMPUAN & & \\
\hline 1 & $0-04$ & 484 & 455 & 239 & \multirow{15}{*}{$\begin{array}{l}\text { - Jmmlah Kepala } \\
\text { Keluarga ( KK) } \\
-2.314 \text { iGK }\end{array}$} \\
\hline 2 & $05-09$ & 345 & $39 \mathrm{~B}$ & 743 & \\
\hline 3 & $10-14$ & 279 & 287 & 566 & \\
\hline 4 & $15-19$ & 300 & 352 & 732 & \\
\hline 5 & $20-24$ & 400 & 501 & प्रU4 & \\
\hline 6 & $25-29$ & 405 & 371 & 776 & \\
\hline 7 & $30-34$ & 3.3 .5 & 280 & 5'15 & \\
\hline f & 3.539 & 391 & 351 & 542 & \\
\hline 9 & $40 \quad 14$ & 247 & 236 & 183 & \\
\hline 10 & $\begin{array}{ll}15 & 19 \\
\end{array}$ & 181 & 167 & 351 & \\
\hline 11 & $50-54$ & 250 & 241 & 491 & \\
\hline 12 & $55-5 y$ & 146 & 140 & 286 & \\
\hline 13 & $60-64$ & 159 & 122 & ZU1 & \\
\hline 14 & $65-69$ & 146 & 129 & 275 & \\
\hline 15 & 70-Keatas & 9.3 & 75 & 168 & \\
\hline \multicolumn{2}{|c|}{ J $\mathbf{n m}$ ' a h } & 4.232 & 4005 & 8.237 & 2.314 \\
\hline
\end{tabular}

Sumber : Data Desa Malasari 2015

Keadaan Penduduk Desa Malasari berdasarkan Agama yang dianut sebagai berikut :

Tabel 2. Keadaan Penduduk Desa Malasari berdasarkan Agama yang Dianut

\begin{tabular}{|l|l|}
\hline Agama & Jumlah \\
\hline Islam & 8.237 \\
\hline Katolik & - \\
\hline Protestan & - \\
\hline Hindhu & - \\
\hline Budha & - \\
\hline Konghucu & - \\
\hline
\end{tabular}

Sumber : Data Desa Malasari 2015 
Untuk data tingkat pendidikan masyarakat Desa Malasari adalah sebagai berikut :

Tabel 3. Tingkat Pendidikan Penduduk Desa Malasari

\begin{tabular}{|c|c|c|}
\hline Tingkat Pendidikan & Jumlah & \\
\hline Tamat SD Sebanyak & 4.800 orang & \\
\hline Tamat SLTP Sebanyak & 601 orang & \\
\hline Tamat SLTA Sebanyak & 280 orang & \\
\hline Tamat Akademi / Sarmud & 42 orang & \\
\hline Tamat Perguruan Tinggi Sarjana & 5 orang & \\
\hline Tamat Tsanawiyah & 227 orang & \\
\hline Tamat Aliyah & 58 orang & \\
\hline Pesantren Salapiah & 170 orang & Sumber : Data De \\
\hline Pesantren Moderen & 10 orang & Malasari ,2015 \\
\hline
\end{tabular}

\section{Potensi Wisata Desa Malasari}

\section{Potensi Daya Tarik Alam}

Desa Malasari memiliki beragam potensi wisata yang menarik untuk bisa dijadikan sebagai salah satu atraksi wisata. Dari keseluruhan sebaran 33 kampung yang ada di dalam daerah administratif Desa Malasari hanya 9 kampung yang memiliki obyek wisata yaitu kampong Nirmala, Citalahab, Cisangku, Cihanjawar, Pasir Banteng, Sijagur dan Legok Jeruk dan Cimalang. Adapun masing-masing kampung tersebut memiliki keragaman obyek wisata yang berbeda satu sama lainnya. Adapun potensipotensi yang ada di Desa Malasari adalah sebagai berikut:

\section{a. Kebun Teh Nirmala}

Perkebunan Teh Nirmala memiliki luas sekitar 900 hektar keberadaan perkebunan yang dikelola oleh swasta melalui kepemilikan hak guna usaha itu menjadi kawasan enclave dalam kawasan taman nasional.

b. Jalur Interpretasi (loop trail)

Jalan setapak Cikaniki - Citalahab sepanjang 3,8 km dibuat pada tahun 1997, jalur ini sengaja dibangun sebagai jalur yang bisa diakses untuk kepentingan penelitian primata di Taman Nasional Gunung Halimun Salak. Pada perkembangannya kemudian jalur penelitian ini menjadi salah satu atraksi wisata yang ditawarkan oleh Taman Nasional bagi kepentingan wisata khususnya wisata yang bertemakan kepada pendidikan dan pelestarian lingkungan.

\section{c. Canopy Trail}

Canopy Trail memiliki 4 Jembatan gantung dengan ketinggian 25 meter dari permukaan tanah. Namun pada pohon ketiga Canopy trail mengalami kebusukan dan akan direnovasi tahun 2016 dari Kementerian Kehutanan. Canopy Trail penggunaannya diresmikan oleh Menteri Kehutanan dan Perkebunan pada masa itu Dr. Ir. Muslimin Nasution. Fungsi dari Canopy trail ini sebagai wahana pengamatan satwa dan untuk melihat keindahan vegetasi hutan taman nasional dari ketinggian.

d. Air Terjun

Kawasan Taman Nasional Gunung Halimun Salak menyimpan keindahan alam yang beragam, salah satunya adalah banyaknya air terjun yang berada di kawasan taman nasional, hal ini membuktikan bahwa memang gunung Halimun merupakan sumber mata air dan hulu dari beberapa sungai besar yang bermuara di laut Jawa dan Samudera Hindia. Terdapat beberapa curug atau air terjun yaitu Curug Cihanjawar, Walet dan Cikudapeh di sekitar perkebunan teh Nirmala, Curug Piit setinggi sekitar 25 meter dan Curug Macan setinggi sekitar 7 meter.
2. Potensi Budaya, Daya tarik Wisata Seni Budaya dan Kerajinan
a. Pagelaran Seren Taun 
Upacara Adat Seren Taun merupakan salah satu upacara adat yang dilakukan oleh masyarakat sunda pada saat panen padi setiap tahun. dengan penuh khidmat dan semarak upacara adat ini berlangsung di berbagai daerah adat sunda. Upacara adat ini mempunyai simbol atau ungkapan rasa syukur masyarakat atas apa yang telah dilakukan dan diraihnya selama bercocok tanam khususnya tanaman padi. Selain digelar dengan khidmat dan sakral, upacara adat Seren Taunpun digelar dengan meriah, kemeriahan upacar ini dengan diikuti berbagai kalangan masyarakat sekitar juga masyarakat dari beberapa daerah di Jawa Barat. Tidak terkecuali tradisi ini pun menjadi tradisi yang dimiliki oleh warga masyarakat Desa Malasari.

b. Seni Musik Tradisional

Seni musik tradisional yang masih ada dan dikembangkan di Desa Malasari adalah gamelan Sunda dan angklung. Gamelan sunda ini masih dipertahankan dan dilestarikan untuk kepentingan persiapan Desa Malasari untuk menerima kunjungan wisatawan. selain itu Gamelan Sunda dan angklung sebagai seni tradisional yang merupakan syarat yang akan di pentaskan dalam perayaan seren taun satu tahun sekali. c. Calung

Calung merupakan alat musik tradisional Jawa Barat yang terdiri dari deretan tabung bambu yang disusun berurutan dengan tangga nada pentatonik dan dimainkan dengan cara memukul bagian bilah atau tabungnya. Bambu yang dipakai untuk membuat alat musik calung berasal dari jenis awi temen atau awi wulung.

d. Tutunggulan

Salah satu kesenian khas dari Jawa Barat ini berawal dari aktifitas masyarakat terutama yang dilakukan oleh para kaum perempuan khususnya ibu-ibu yang menumbuk padi dengan lesung (alat penumbuk padi). Tutunggulan berasal dari kata nutu, yang berarti menumbuk (biasanya berupa gabah untuk dijadikan beras, ataupun beras untuk dijadikan tepung). Tetapi seiring dengan berjalannya waktu kesenian ini digunakan juga untuk menyambut tamu, atau pada upacara tertentu. Bahkan Tutunggulan digunakan juga sebagai salah satu pengisi acara kebudayaan mereka sendiri, yaitu seren taun.

\section{Potensi Sejarah}

Berubah menjadi desa pada masa kepemimpinan Bapak Ining yang memerintah selama 24 tahun (1942 - 1966). Kala itu politik nasional masih bergejolak, dimana pihak kolonial Belanda masih belum mengakui kemerdekaan Republik Indonesia, maka melalui tentara sekutunya Belanda melakukan Agresi Militer II dan berhasil menguasai wilayah perkotaan termasuk wilayah kabupaten Bogor. Oleh karenanya, Bupati Bogor ketika itu, H.R. Ipik Gandamana Sumawinata, mengungsi ke Desa Malasari, dan memimpin pemerintahan dari tempat pengungsiannya tersebut selama kurang lebih 2 tahun (1947-1949). Adapun bekas pengungsiannya hingga kini dilestarikan menjadi situs/cagar budaya oleh pemerintah Desa Malasari.

\section{Pengelolaan Ekowisata Halimun Desa Malasari}

Upaya meningkatkan ekonomi masyarakat, Pemerintah Desa (Pemdes) Malasari bekerjasama dengan CV Pesona Malasari, Perhutani, Taman Nasional Gunung Halimun Salak (TNHGS) dan masyarakat setempat yang tergabung dalam Kelompok Swadaya Masyarakat (KSM) untuk memanfaatkan potensi dan sumber daya yang banyak dimiliki diwilayah tersebut diantaranya, Sumberdaya alam, dengan membuat salah satu konsep yakni Desa Wisata Malasari (DWM) yang sudah berjalan bahkan sudah mendapatkan Surat Keputusan Kepala Desa dengan Nomor 144/14SK.Kades/2015 dan telah menjadi Badan Usaha Milik Desa (BUMDES) yang di namakan "BUMDES Sauyunan" dengan SK Nomor. 141/04/KPTS/2015.

Adapun secara kelembagaan, ekowisata Halimun yang selama ini berjalan di Desa Malasari dikelola secara swadaya oleh masyarakat. Kelembagaan yang terlibat di antaranya Kelompok Swadaya Masyarakat (KSM), Pesona Malasari, BUMDES, Kepengurusan Desa Wisata Malasari. 
Kelompok Swadaya Masyarakat Desa Malasari merupakan sebuah kelembagaan masyarakat yang terdapat di Desa Malasari. Pengelolaan kegiatan dilakukan dengan cara berkelompok. Hasil dari pengelolaan kegiatan wisata dialokasikan untuk kepentingan sosial, pendidikan, dan keagamaan serta ketertiban, yang selanjutnya dikelola oleh pemerintah desa. Terbentuknya Kelompok Swadaya Masyarakat Desa Malasari sendiri baru terbentuk di tahun ini. Mereka baru terbentuk karena baru ada struktur yang jelas dan rencana-rencana yang jelas untuk pengembangan desa wisata serta program ekowisata yang bisa dilakukan di Desa Malasari. Kontribusi yang dilakukan oleh pihak Kelompok Swadaya Masyarakat ini diantaranya memperdayakan masyarakat sekitar untuk ikut terlibat ke dalam kegiatan yang ada di Desa Malasari. Gunanya untuk mengasah kreatifitas masyarakat agar tidak mengalami ketergantungan denga program kerja yang sudah ada. Sehingga bisa memberikan inovasi atau ide baru yang bermanfaat.

\section{Struktur Organisasi Desa Wisata} Malasari

$\begin{array}{lll}\text { Ketua } & : & \text { U Suryana } \\ \text { Sekretaris } & : & \text { Usman Usmana } \\ \text { Bendahara } & : & \text { Rukiah } \\ \text { Bidang/seksi } & & \end{array}$

a. Pemandu :

1) Ade

2) Sopian

3) Suryadi

Bidang/seksi

b. Kuliner dan Homesstay :
1) Rais
2) Lilis
3) Hendi

Bidang/seksi

c. Peralatan dan pengembangan potensi:

1) Hendrik

2) Kosnadin

3) Awan

Bidang/seksi

d. Pemberdayaan ekonomi dan kelembagaan:
1) Odang

2) Pupud

3) Ipin

Pembangunan kepariwisataan Desa Wisata Malasari bertujuan melestarikan kondisi lingkungan yang memacu terjadinya pertumbuhan ekonomi lokal dalam bentuk pariwisata yang ramah, sehingga dapat menjadi stimulator bagi sektor lain seperti industri kreatif dan usaha kecil menengah dalam rangka meningkatkan kesejahteraan ekonomi masyarakat dari sektor pariwisata dengan berpijak pada prinsip-prinsip Community Based Tourism (CBT).

Pembangunan kepariwisataan Desa Wisata Malasari menurut Sekretaris Desa Bapak Sukandar juga dilakukan dengan semangat partisipatif. Masyarakat secara langsung dilibatkan untuk merencanakan, mengkoordinasikan, mengontrol, melaksanakan dan mengelola pariwisata sebagai wujud keseriusan dan kesiapan masyarakat dan pemerintah Desa Malasari untuk mendukung keberhasilan pengembangan wisata di Desa Wisata Malasari dan mengembangkan ekowisata sesuai dengan situasi, kondisi dan potensi yang ada.

\section{PEMBAHASAN}

Dalam menyusun perencanaan pengembangan pariwisata, Pemerintah Kabupaten Bogor merujuk kepada Peraturan Daerah Kabupaten Bogor Nomor 3 Tahun 2013 tentang kepariwisataan dimana masyarakat memiliki kesempatan yang sama dan seluas-luasnya dalam proses pengambilan keputusan di bidang kepariwisatan. Peran serta masyarakat sebagaimana dimaksud berupa pemberian saran, pertimbangan, pendapat, tanggapan, pengawasan, keberatan, pengaduan, penyampaian informasi atau laporan terhadap pengembangan, informasi potensi dan masalah, serta rencana pengembangan kepariwisataan.

Partisipasi dalam pengambilan keputusan yang dilakukan melalui mekanisme rapat pertemuan yang diadakan di tingkat desa 
dan ditingkat pengelola ekowisata Halimun. Dalam pertemuan tersebut dibahas mengenai pengembangan potensi desa dalam bidang pariwisata sehubungan dengan keberadaan potensi yang dimiliki oleh Desa Malasari. Dalam penelitian ini kemudian dilihat bagaimana masyarakat ikut hadir dalam pertemuan yang diikuti dan intensitas pertemuan yang diikuti, peran dalam pertemuan, keaktifan dalam memberi masukan, merasakan kejelasan mengenai permasalahan yang dibahas, penerimaan hasil keputusan dalam pertemuan, bagaimana masyarakat menerima sosialisasi mengenai pengembangan wisata, penerimaan usulan yang disampaikan, keterlibatan dalam mengidentifikasi permasalahan hingga sosialisasi dari hasil keputusan untuk pengembangan wisata.Bentuk partisipasi pada tahapan ini adalah masyarakat menginginkan Desa Malasari bisa berkembang, dan salah satu bentuk pengembangannya adalah menjadikan Desa Malasari sebagai Desa Wisata.

Partisipasi masyarakat dalam proses pelaksanaan pengembangan wisata, dapat diwujudkan melalui partisipasi dalam menjalankan rencana yang telah ditetapkan dengan memberikan bantuan tenaga, uang ataupun materi. Baik itu dalam usaha peningkatan sarana dan prasarana penunjang obyek wisata maupun peningkatan daya tarik wisata sehingga kebutuhan wisatawan yang berkunjung akan terpenuhi. Berdasarkan informasi masyarakatpun, mereka menyatakan bahwa mereka ikut berpartisipasi karena kesadaran sendiri dan mulai sudah paham akan peranannya dalam pengembangan wisata di daerahnya. Sedangkan untuk masyarakat yang tidak berpartisipasi menyebutkan bahwa adanya faktor-faktor lain yang menyebabkan mereka tidak terlibat yaitu mereka tidak sepenuhnya bergantung secara ekonomi terhadap aktivitas pariwisata karena berbagai hal misalnya kesibukan akan pekerjaan. Kesadaran masyarakat untuk berpartisipasi, selain dilihat dari keikutsertaan mereka dalam kegiatan- kegiatan event yang dilaksanakan di Desa Malasari, juga dapat dilihat dari kegiatan mereka dalam kegiatan kebersihan lingkungan, ikut menjaga keamanan lingkungan dan juga keikutsertaan masyarakat dalam pelatihan-pelatihan yang dilakukan oleh DISPAR Kabupaten Bogor. Dalam pengembangan wisata di Desa Malasari, pengembangan kelembagaan dan sumber daya manusia menjadi hal yang sangat penting. Dalam program pengembangan kelembagaan dan sumber daya manusia, Dinas Pariwisata Kabupaten Bogor memiliki fungsi pembinaan dan pengembangan destinasi turut pula berpartisipasi dalam pengembangan kelembagaan dan sumber daya manusianya. Berbagai pelatihan yang mengedepankan aspek pelayanan seperti manajemen pelayanan, pengelolaan wisatawan di destinasi wisata, pengembangan atraksi dan fasilitas wisata dilakukan dan diikuti oleh masyarakat. Untuk mendukung pengembangan wisata, pemerintah kemudian mensponsori pembentukan lembaga Desa Wisata walaupun belumlah optimal dalam pengelolaan kelembagaan tersebut

Partisipasi masyarakat secara alamiah terjadi pada pelaksanaan event budaya seperti seren taun yang ada di Desa Malasari. Semua tingkatan bentuk partisipasi terlihat dari partisipasi pemikiran, tenaga dan materi. Untuk partisipasi dalam gagasan dan pemikiran terlihat misalnya dalam rapatrapat yang dilaksanakan dalam menjelang pelaksanaan serta kesediaan untuk hadir dari perwakilan tokoh pemuda dan masyarakat dalam pertemuan yang digagas oleh Desa Malasari.

Partisipasi masyarakat dalam bentuk tenaga bisa terlihat pada saat hari pelaksanaan seren taun. Kepanitiaan yang terbentuk akan bekerja sesuai dengan peran dan tanggung jawabnya yang sifatnya sukarela tanpa insentif. Diluar kepanitiaan pelaksana pun, masyarakat ikut berpartisipasi sebagai peserta yang menjadi bagian dari prosesi seren taun tersebut. Contohnya adalah kesediaan masyarakat 
untuk memberikan sumbangan materi dalam bentuk olahan hasil bumi dari tiap-tiap warga masyarakat yang mampu dan ingin berpartisipasi dalam prosesi yang dinamakan helaran dongdang (ngarak dongdang). Dongdang adalah aneka hasil bumi yang dikemas dalam bentuk keranjang yang dihias sebagai bentuk persembahan syukur yang kemudian dibagikan pada saat acara puncak.

Hasil-hasil dari pengembangan wisata yang telah dicapai haruslah dipelihara dengan baik agar pemanfaatannya dapat dirasakan oleh masyarakat. Selain daripada itu harapan untuk masyarakat adalah dapat menjaga dan mengembangkannya sehingga lebih bermanfaat untuk jangka waktu yang lebih lama.

Berdasarkan data temuan lapangan partisipasi masyarakat dalam proses pemanfaatan dapat dilihat dari tindakan masyarakat untuk menjaga dan merawat hasil-hasil pembangunan dengan baik. Mencegah terjadinya pengrusakan, mengatasi dan memperbaiki kerusahakankerusakan di objek wisata tersebut. Melaporkan kepada yang berkompeten apabila apabila terjadi hal-hal yang tidak dapat diatasi. Tindakan lain adalah mengumpulkan dan menghimpun dana dalam segala bentuk yang ditujukan untuk pemeliharaan aset-aset wisata yang ada. Masyarakat merasakan manfaat akan keberadaan dari adanya kegiatan ekowisata di Desa Malasari tersebut, hal ini tercermin dari tingginya keinginan masyarakat untuk berpartisipasi dalam pengembangan Ekowisata Desa Malasari. Keberadaan ekowisata Halimun bagi masyarakat Desa Malasari memberikan manfaat, terutama dalam sektor ekonomi yang dapat meningkatkan pendapatan mereka, sekaligus bagi masyarakat bisa memberikan kesempatan kerja bagi masyarakat diluar mata pencaharian utama.

Dalam tahapan evaluasi, Masyarakat berpartisipasi dalam pemanfaatan dan pemeliharaan fasilitas wisata ekowisata Desa Malasari. Walaupun pada praktek dan bentuknya, pemanfaatan tersebut tidak harus selalu yang berkaitan dengan tujuan pengembangan ekowisata Desa Malasari sebagai kawasan yang merevitalisasi seni dan tradisi dan menyelenggarakan wisata budaya, bahkan kecenderungannya sudah melebar terhadap pemanfaatan dengan motivasi yang lain seperti pemanfaatan sarana dan prasarana untuk kepentingan sosial kemasyarakatan. Sehingga dari uraian di atas dapat disimpulkan bahwa masyarakat dalam pemanfaatan dan pemeliharaan hasilhasil pembangunan dan pengembangan ekowisata Desa Malasari dinilai positif.

\section{KESIMPULAN}

Faktor yang cukup dominan dalam permasalahan partisipasi masyarakat dalam pengembangan wisata Desa Malasari adalah adalah kurangnya sosialisasi dan komunikasi kepada masyarakat mengenai tujuan jangka panjang pengembangan wisata Desa Malasari. Disinilah perlunya model partisipasi masyarakat dengan menggunakan peran para tokoh-tokoh masyarakat dalam meningkatkan partisipasi masyarakatnya.

Pemerintah Kabupaten Bogor dalam hal ini Dinas Pariwisata perlu membangun stakeholder terkait yang merupakan pendukung dari pengembangan wisata di Desa Wisata Malasari yang terdiri dari pemerintah, tokoh masyarakat, perwakilan kelompok masyarakat, dan sektor swasta sebagai bagian dari komponen pengembangan wisata di Desa Wisata Malasari.

Setiap kebijakan dan program perencanaan pengembangan perlu diinformasikan dan disosialisasikan secara intensif kepada lapisan masyarakat yang paling bawah sekalipun. Dengan mengetahui dan memahami, diyakini masyarakat dapat berpartisipasi aktif dalam memberikan dukungan berbagai program pengembangan Desa Wisata Malasari.

Perlunya masyarakat diberikan peluang partisipasi yang lebih besar untuk lebih terlibat dalam berbagai program pengembangan dengan jalan mendesain sebuah ruang partisipasi yang dapat menampung aspirasi dan partisipasi masyarakat yang lebih luas. 
Desa Malasari memiliki banyak potensi wisata yang ari dilakukan pengembangan yang lebih luas. Desa Malasari memiliki potensi seni budaya yang ari dikembangkan menjadi aktivitas wisata budaya seperti seni tradisional calung, ritual adat seren taun yang diselenggarakan satu tahun sekali sebagai tradisi yang di hidupkan kembali oleh masyarakat Desa Malasari. Selain kesenian, potensi wisata Desa Malasari dilengkapi pula oleh kerajinan masyarakat sebagai pelengkap daya arik bagi wisatawan yang berkunjung ke Desa Malasari. Desa Malasari merupakan salah satu desa yang memiliki potensi yang beragam untuk dikembangkan menjadi daya arik wisata.

Dengan status Desa Malasari sebagai Desa Wisata, pihak desa semakin giat bersama masyarakat memusyawarahkan mengenai program maupun perencanaan yang akan dilakukan untuk menunjang aktifitas pariwisata yang kedepannya diharapkan mampu meningkatkan perekonomian masyarakat. Bentuk partisipasi yang dilakukan masyarakat dalam pengembangan desa wisata seperti : (1) Bentuk partisipasi yang mengawali aktifitas kepariwisataan yaitu masyarakat membuka usaha seperti warung makan, homestay dan pemandu wisata. (2) Bentuk partisipasi proses awal kepariwisataan yaitu masyarakat mulai melakukan musyawarah bersama untuk membicarakan mengenai keinginan mereka tehadap aktivitas pariwisata di desa mereka.

Bentuk partisipasi dalam tahap pengambilan keputusan untuk perencanaan yaitu pembentukan unit usaha Pesona Malasari, pembuatan sarana dan prasarana yang menunjang kepariwisataan.

\section{REFERENSI}

Annisa. (2017).Community Participation In The Implementation Of Tourist Village Rantih Sawahlunto . JOM FISIP Vol. 4 No. 2 - Oktober 2017

Eko Budi S. (2001). Ecotourism Pada Tingkat Komunitas Di Kawasan Wisata Pangandaran Provinsi Jawa Barat. Jurnal Widyapraja Volume 43/No. 1/Oktober $2017: 1-20$

Prastiwi Mardija. (2010). Partisipasi Masyarakat Terhadap Peningkatan Pembangunan Desa. Buletin Ekonomi Vol. 8, No. 1, hal 1-70

Siti Irene Astuti D. (2011). Desentralisasi dan Partisipasi Masyarakat Dalam Pendidikan. Yogyakarta: Pustaka Pelajar

Sri Hayati. (2010). Partisipasi Masyarakat Dalam Pengembangan Ekowisata DI Pangandaran - Jawa Barat. Jurnal Forum Geografi, Vol. 24, No. 1, Juli 2010: 12 - 27)

The Ecotourism Society. Konsep Ekowisata, https://www.ecotourism.org/what-isecotourism . Di unduh pada 15 Nov 2018 